
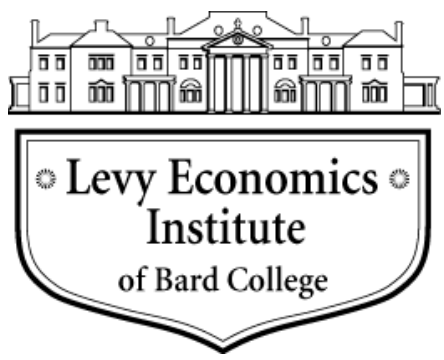

Working Paper No. 925

\title{
An Institutional Analysis of China's Reform of their Monetary Policy Framework
}

\author{
by \\ He Zengping \\ Renmin University of China \\ and \\ Jia Genliang \\ Renmin University of China and \\ Collaborative Innovation Center for China Economy
}

\section{April 2019}

The authors would like to thank Jan Kregel and L. Randall Wray for their helpful and constructive comments, and Elizabeth Dunn for her editing work. All remaining errors are the authors'.

The Levy Economics Institute Working Paper Collection presents research in progress by Levy Institute scholars and conference participants. The purpose of the series is to disseminate ideas to and elicit comments from academics and professionals.

Levy Economics Institute of Bard College, founded in 1986, is a nonprofit, nonpartisan, independently funded research organization devoted to public service. Through scholarship and economic research it generates viable, effective public policy responses to important economic problems that profoundly affect the quality of life in the United States and abroad.

\author{
Levy Economics Institute \\ P.O. Box 5000 \\ Annandale-on-Hudson, NY 12504-5000 \\ http://www.levyinstitute.org
}

Copyright (C) Levy Economics Institute 2019 All rights reserved

ISSN 1547-366X 


\begin{abstract}
This paper traces the history of China's reform of its monetary policy framework and analyzes its success and problems. In the context of financial marketization and the failure of the quantity-targeting framework, the People's Bank of China transformed its monetary policy framework toward one that targets interest rates. The reform includes two important institutional changes: establishing an interest rate corridor and decreasing the difficulty the Open Market Operations room faces in estimating the market demand for reserves. The new monetary policy framework successfully stabilizes the interbank offered rate. However, this does not mean that the new framework is sufficient. One important problem remaining to be solved is how to manage the effects of fiscal activities on monetary policy operations. This paper analyzes the fiscal effects on reserves in China's Treasury Single Account system. The missing role of the Treasury in monetary policy operations increases the difficulty for the central bank to achieve its interest rate target. A further reform is therefore needed to provide a coordination mechanism between the Treasury and the People's Bank of China.
\end{abstract}

KEYWORDS: China; Monetary Policy Framework; Interest Rate Target; Fiscal Effects on Reserves

JEL CLASSIFICATIONS: E42; E52; E58; P24 


\section{INTRODUCTION}

China's central bank, the People's Bank of China (PBOC), implemented a large-scale reform to its monetary policy framework in the new century. The main purpose of the reform was to lay down the institutional basis for an interest rate targeting monetary policy framework. Although nominally the official intermediate target at present is still money quantity (M2 and "Social Financing Scale"), a shift to an interest rate target is upcoming. In 2018, the "Report on the Work of the Government" (Central People's Government of the People's Republic of China 2018) stopped declaring a quantity target for monetary policy. This seems to show that the institutional transformation to a new monetary policy framework has come to its final stage.

This paper aims to trace the history of China's reform of its monetary policy framework in the new century and to provide an institutional analysis of its success and problems. As a transitional economy, China's monetary policy framework based on a quantity target is to some extent an institutional legacy of a planned economy where financial activity was controlled directly via a credit plan (Xiaochuan 2004). The marketization of China's economy forced the PBOC to abandon its direct control of the financial markets, but the money quantity target remained an important part of the monetary policy framework. In the new century, especially since 2008, it has become more and more obvious that this framework is problematic in the market system, when the money quantity becomes hard to control and the fluctuations of the interbank offered rate become severe. This pushed the PBOC to adjust its monetary policy framework. The reform has proven to be successful. As shown in figure 1, the severe fluctuation in the Shanghai Interbank Offered Rate (Shibor) has been reduced to a much lower level. 
In the second section, the paper will analyze the institutional reasons for the reform's success, as well as the interest rate maintenance mode of China and two important institutional changes in China's monetary policy framework: establishing an interest rate corridor and decreasing the difficulty for the Open Market Operations room (OMOR) in estimating the market demand for reserves. These changes provide the institutional basis for a price targeting framework.

\section{Figure 1. 60-Working-Day Rolling Standard Deviation of Shanghai Interbank Offered Rate (Shibor)}

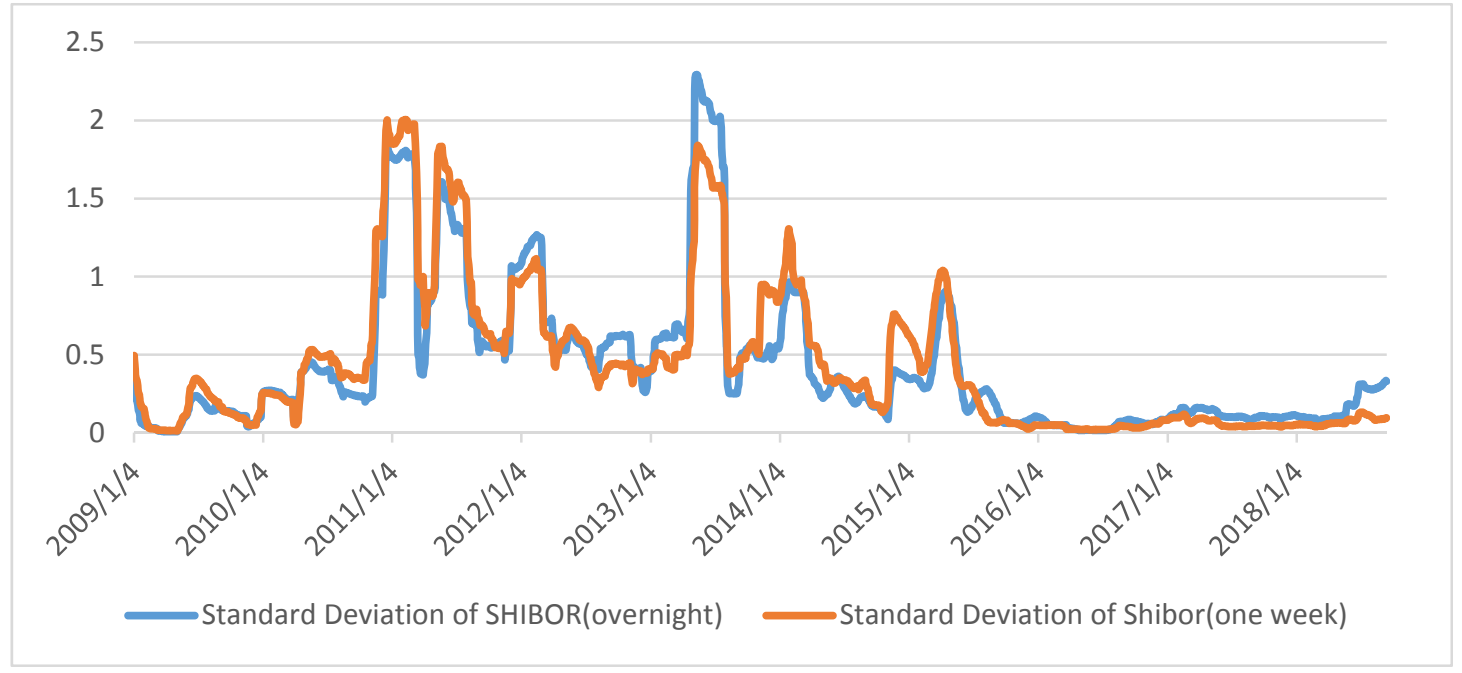

Source: China Foreign Exchange Trade System \& National Interbank Funding Center's website: www.chinamoney.com.cn

This success does not mean that the new monetary policy framework has become mature. The PBOC's interest rate maintenance mode - which means the way it achieves and maintains its target rate-is similar to the Federal Reserve's. Compared to the Federal Reserve, where fluctuation in the federal funds rate is within a few basis points most of time, the fluctuation of the Shibor is still large. Some problems in official benchmark rates and reserve requirements will also be discussed in the second section. In the third section the paper will discuss an important problem in the new monetary policy framework, namely, the missing role of the Treasury, as well as an institutional analysis of the Chinese Treasury's Single Account system, 
showing that the lack of a coordination mechanism between the Treasury and the PBOC decreases the PBOC's ability to stabilize the interbank offered rate. As Modern Money Theory (MMT) states, Treasury spending creates money and Treasury taxing destroys it; therefore the Treasury plays an important role in monetary policy operations (Bell 2000; Bell and Wray 2002; Tymoigne 2014; Wray 2015). ${ }^{1}$ The fourth section concludes and offers some policy recommendations.

\section{THE EVOLUTION OF CHINA'S MONETARY POLICY FRAMEWORK}

\section{The Quantity-Targeting Monetary Policy Framework}

Since 1998, the intermediate target of monetary policy in China has been money quantity. The quantity of money is measured by M2 and, beginning in 2011, a new indicator called the "social financing scale" was introduced to complement the M2 measure. This quantity-targeting monetary policy framework is a legacy of the planned economy: "Before 1998, implementation of monetary policy by the PBOC was through the credit plan, which was an aggregate of industry and local financing needs compiled from the bottom up" (Leung and Lu 2011). The credit quota system was formally abandoned in 1998, but it is easy to see its shadow in the central bank's attempt to control money quantity. Besides, the price formation mechanism in the financial markets was not mature at that time and many kinds of interest rates were still under the government's direct control. This also made the quantity target preferable to a price target.

\footnotetext{
${ }^{1}$ We will discuss briefly some propositions of MMT in China's institutional settings in the appendix.
} 
However, in the process of China's financial marketization, the quantity-targeting monetary policy framework became more and more unsuitable for monetary policy operations.

First, the quantity target was hard to achieve in practice. In a general case, considering that the market demand for reserves for making settlements is highly interest inelastic, it is hard for the central bank to refuse the market demand and to stick to its target. Otherwise, the domestic payment system would be unstable or even fall into a liquidity crisis, and this is totally against the central bank's responsibility of keeping its domestic payment system stable. When the market demand is not met, deposit reserve requirements and excess reserves may provide a cushion for the shortage of reserves so that a liquidity crisis will not happen immediately, but the fluctuations in interest rates will be severe, which is also harmful to the stability of financial markets. Thus, the quantity target is problematic and an interest rate target is preferable (Fullwiler 2013). If the central bank is always ready to meet the market demand for reserves at its target rate, it can hit its interest rate target. In practice, it means that in order to keep the interest rate at its target, some monetary policy tools are needed to help the central bank know the market demand and meet it.

In China's previous monetary policy framework, the money quantity target was set by the central government and announced in the Chinese government's annual "Report on the Work of the Government." If we compare the target with the actual growth of M2, the PBOC's money quantity target was not precisely achieved. As shown in table 1, the actual growth sometimes deviated greatly from the target. 
Table 1. Growth Target and Growth of M2

\begin{tabular}{|l|r|r|r|r|r|r|r|r|r|}
\hline Year & $\mathbf{2 0 0 9}$ & $\mathbf{2 0 1 0}$ & $\mathbf{2 0 1 1}$ & $\mathbf{2 0 1 2}$ & $\mathbf{2 0 1 3}$ & $\mathbf{2 0 1 4}$ & $\mathbf{2 0 1 5}$ & $\mathbf{2 0 1 6}$ & \multicolumn{2}{|c|}{$\mathbf{2 0 1 7}$} \\
\hline $\begin{array}{l}\text { Growth } \\
\text { Target of M2 }\end{array}$ & $17 \%$ & $17 \%$ & $16 \%$ & $14 \%$ & $13 \%$ & $13 \%$ & $12 \%$ & $13 \%$ & $12 \%$ \\
\hline $\begin{array}{l}\text { Growth of } \\
\text { M2 }\end{array}$ & $28.42 \%$ & $18.95 \%$ & $17.32 \%$ & $14.39 \%$ & $13.59 \%$ & $11.01 \%$ & $13.34 \%$ & $11.33 \%$ & $8.17 \%$ \\
\hline
\end{tabular}

Source: CEInet Industry Database and Report on the Work of the Government

Second, the fluctuation of market interest rates became severe, as shown in figure 1. However, because it is ambiguous how the money quantity target was determined and to what extent the PBOC insisted on the target, it is hard to say to what extent the attempt to achieve a quantity target caused the fluctuation in interest rates. Some evidence shows that the PBOC accommodated the market demand for reserves rather than provide reserves according to its target. On some high-payment-flow days, like Spring Festival (Chinese New Year) periods, it was stated clearly that the main purpose of open market operations was to smooth "the fluctuation of the supply and demand of liquidity in banking system” (PBOC 2009).

Third, financial innovations made M2 a weak indicator of the whole picture of financial activity. With the rapid development of China's financial market, financial institutions became adapted to a marketization environment and the motive to seek profit drove them to make financial innovations in order to avoid interest rate controls and other regulations on traditional banking business. Although in 2018 the PBOC adjusted the scope of M2 to include money market funds held by nondepository institutions, it states clearly that "revising the scope of the M2 indicator does not fundamentally resolve the declining effectiveness of the quantitative indicators. In light of the requirement for high-quality development, it is necessary to follow the laws of economic and financial development and to transform the method of macroeconomic management by gradually shifting from quantity-based indicators to interest rates and other price-based 
indicators" (PBOC 2018).

In short, as the legacy of a planned economy, the quantity-targeting monetary policy framework faces challenges from the rapidly developing financial market. The PBOC admits that "the measurability and controllability of $\mathrm{M} 2$ and its relevance to the real economy have been weakening" (Zhong 2018; Gang 2018; PBOC 2017b). All of these reasons pushed the PBOC to reform its monetary policy framework, requiring not only a change of the intermediate target, but also further institutional adjustments to solve the problems in the previous framework.

\section{The Interest Rate Maintenance Mode in China}

In China's monetary policy framework, the interest rate maintenance mode is similar to that of the United States. In these kinds of interest rate maintenance modes, a central bank sets an interest rate corridor to control the range of the interbank offered rate's fluctuations. The floor of the interest rate corridor is the interest rate paid on excess reserves and the ceiling is the interest rate on borrowing from the central bank (from the discount window, for example). When the market rate reaches the floor or the ceiling, the interest rate corridor enables the central bank to accommodate market demand for reserves passively and to stabilize the interest rate without difficulty in estimating this demand. If the interbank offered rate rises to the ceiling - because commercial banks can always obtain reserves from the central bank at the ceiling rate - the commercial banks would not borrow reserves from other banks at the rate higher than the ceiling rate and the rate would not go higher; if the rate declines to the floor-because the commercial banks can always earn interest at the floor rate from its excess reserves - the commercial banks would not lend reserves to other banks at a rate lower than the floor rate and thus the rate would not go lower. The interbank offered rate therefore is kept within the interest rate corridor. 
A central bank can choose to set the spread of its interest corridor to zero, but in the interest rate maintenance modes of China and the United States, the spread is larger than zero. In such institutional settings, if the target rate is set within the interest rate corridor, how precisely the central bank can achieve the target rate would not only depend on how small the spread is but also on how precisely the central bank is able to estimate and meet the market demand for reserves at the target rate via its open market operations. If its estimation of the market demand for reserves greatly deviates from the true value, the interbank offered rate will deviate from the target.

In China's previous monetary policy framework, while the floor of its interest rate corridor was provided by the interest rate paid for commercial banks' excess reserves in their accounts at the PBOC, there was no effective monetary policy tools for setting the ceiling. The rediscounting facility of the PBOC was subject to quotas and other controls on the commercial bills that could be rediscounted and the financial institutions that could obtain reserves from the rediscounting facility. Therefore, it was difficult and inconvenient for financial institutions to get access to the rediscounting facility for reserves. If a commercial bank failed to meet the reserve requirement, it would face a 21.6 percent penalty annual interest rate. The punishment for overdraft in the accounts at the PBOC was much heavier.

Open market operations were also constrained. As stated above, the ability of the OMOR to estimate and meet the market demand for reserves plays a key role in achieving the target rate. In the previous monetary policy framework, it was not an easy task, because open market operations were conducted only twice a week (in the morning every Tuesday and Thursday). The infrequence of the open market operations meant that the OMOR had to estimate the market 
demand for reserves over a longer period. ${ }^{2}$

In addition, the difficulty in estimating market demand for reserves was further increased by financial innovations and the fluctuation of foreign capital inflow. China's "Monetary Policy Report" states that "in the past changes in loans and the RMB [renminbi] equivalent of official foreign-exchange holdings could accurately indicate changes in monetary aggregates" (PBOC 2013b). But this linkage was broken due to the fast growth of interbank deposits created by different forms of interbank business, which is hard to supervise. This made the demand for reserves to meet reserve requirements more unstable and harder to predict. Besides, after the reform of the RMB exchange rate formation mechanism in 2012, foreign capital inflow slowed down and became more unstable. This also made it hard to predict the market demand for reserves.

\section{The Reform of the Monetary Policy Framework}

As shown in table 3, since 2013, the PBOC has implemented a series of institutional reforms to its monetary policy operations and introduced several new policy tools. These reforms can be summarized as two key points: 1) establishing an interest rate corridor; and 2) decreasing the difficulty of the OMOR in estimating the market demand for reserves.

\footnotetext{
${ }^{2}$ Besides repurchase agreements, the PBOC issued central bank bills to drain reserves in the market. This was largely due to the slow growth of government bonds, which could not meet the central bank's need. This is a typical story of Modern Money Theory in which the central bank, as a part of the central government, issued bonds so as to achieve the target rate rather than to get financed for its spending.
} 
Table 2. New Monetary Policy Tools and Institutional Changes after 2013

\begin{tabular}{|l|l|}
\hline Date (Year/Month) & New Policy Tools and Institutional Changes \\
\hline 2013/January & Standing Lending Facility (SLF) \\
\hline 2013/January & Short-term Liquidity Operations (SLO) \\
\hline 2014/September & Medium-term Lending Facility (MLF) \\
\hline 2015/September & Required Reserves Assessment Method \\
\hline 2016/February & Daily Open Market Operations \\
\hline 2018/January & Contingent Reserve Arrangement (CRA) \\
\hline
\end{tabular}

In 2013, the PBOC established the Standing Lending Facility (SLF) so as to set up the ceiling of its interest rate corridor. This facility became mature in 2015. It provides reserves on demand to financial institutions with collateral. Its interest rate therefore sets the ceiling for the interbank offered rate's fluctuation. Figure 2 shows the relation between the interbank offered rate and the interest rate corridor. The Shibor kept staying in the spread.

\section{Figure 2. Interest Rate Corridor}

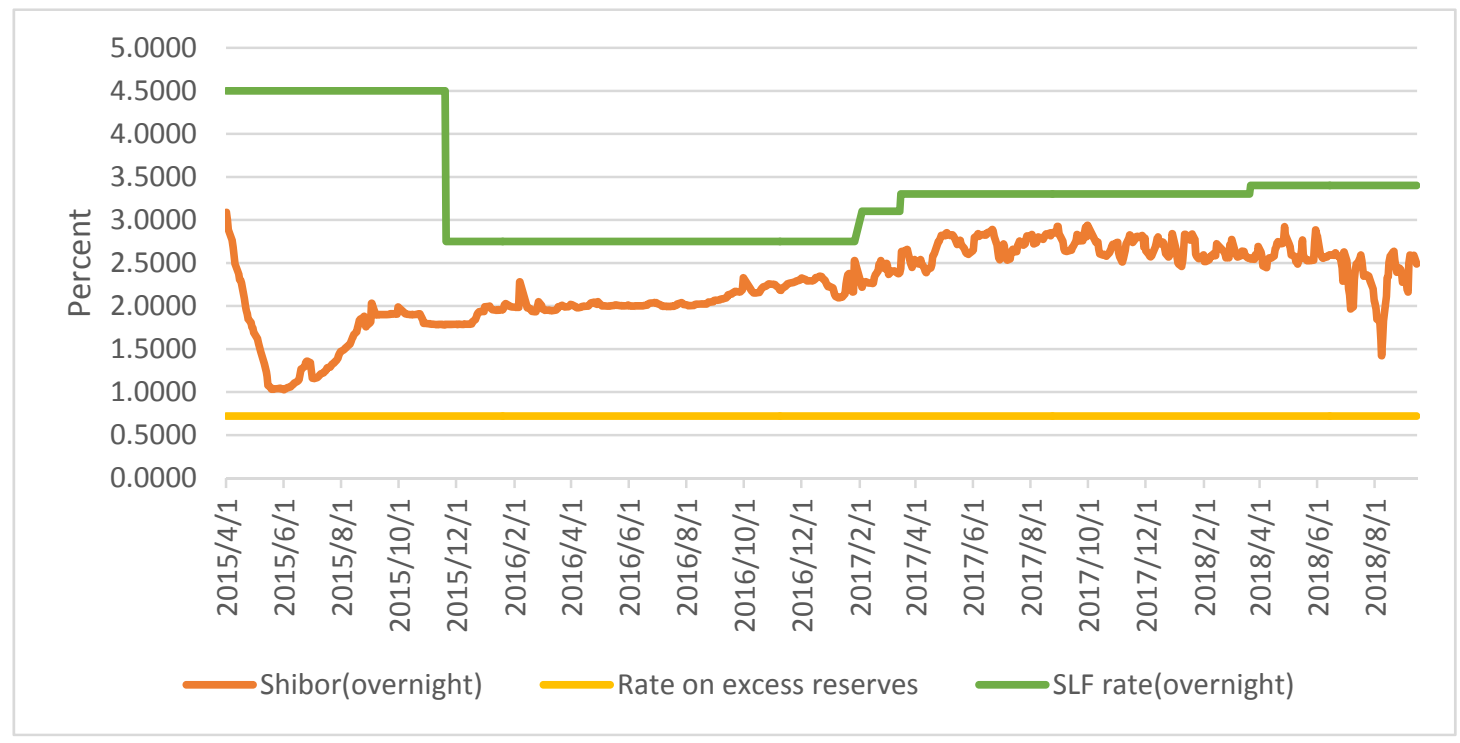

Source: China Foreign Exchange Trade System \& National Interbank Funding Center's website (www.chinamoney.com.cn) and the People's Bank of China's website (www.pbc.gov.cn) 
On the other hand, the reform of the open market operations aimed at decreasing the OMOR's difficulty in making a precise estimation of the market demand for reserves. At the start of 2014, short-term liquidity operations (SLO) were established as a new policy tool that functioned as a temporary complement to the infrequent open market operations in the high-payment-flow periods. In the Spring Festival period of 2014, SLO were carried out and effectively offset the fluctuation of the market rate (PBOC 2013a). The success of the SLO encouraged the PBOC to further reform its open market operations. Starting in February 2016, the OMOR began conducting open market operations on a daily basis. And from then on, SLO were deactivated. In addition to increasing the frequency of open market operations, the difficulty in estimating market demand was further reduced with some other new policy tools. In 2018, the PBOC established the contingent reserve arrangement (CRA) to provide reserves in high-payment-flow periods. Under this arrangement, in the Spring Festival period of 2018, eligible financial institutions could withdraw their required reserves as they needed within a certain percentage range to deal with shortages. The burden on the OMOR to provide reserves therefore was reduced. Besides, the PBOC also established a medium-term lending facility (MLF) in 2014 to affect medium-term interest rates.

In addition, the principle of open market operations became clear in this period. It is summed up as "peak shaving and valley filling" (PBOC 2017a), which means providing reserves when the demand for reserves is high and absorbing reserves when the demand is low. This principle shows that instead of controlling money quantity, the OMOR accommodates the market demand in its daily operations.

Finally, it is worth mentioning that most interest rate controls have been abandoned now. The deregulation of interest rates was achieved step by step. In most cases the government allowed 
the rate to float within a small range around the official rate in the first step of the deregulation and then extended the range gradually until it finally abandoned the direct control. Table 2 shows the dates when different kinds of interest rates were finally deregulated. After the RMB deposit interest rate was deregulated in 2015 , basically all kinds of interest rates had been deregulated. However, as a legacy of the interest rate control, the PBOC continues announcing the official deposit and lending benchmark rates of the RMB, even though the control on deposit and lending interest rates has been abandoned.

Table 3. The Process of China's Interest Rate Deregulation

\begin{tabular}{|l|l|}
\hline Date (Year/Month) & Interest Rate Deregulated \\
\hline $1996 /$ June & Interbank offered rate \\
\hline $1997 /$ June & Repurchase rate in interbank bond market \\
\hline $2000 /$ September & Foreign currency loan interest rate \\
\hline $2004 /$ November & $\begin{array}{l}\text { Foreign currency deposit (less than } 3 \text { million } \\
\text { dollars and more than one year) interest rate }\end{array}$ \\
\hline $2013 /$ July & RMB loan interest rate \\
\hline $2015 /$ May & $\begin{array}{l}\text { Foreign currency deposit (less than } 3 \text { million } \\
\text { dollars) interest rate }\end{array}$ \\
\hline $2015 /$ October & RMB deposit interest rate \\
\hline
\end{tabular}

\section{The Success and Problems of the New Framework}

These institutional reforms have proved to be successful so far in reducing the fluctuation of the interbank offered rate. This can also be seen in the decrease in the fluctuation of the Shibor during Spring Festival periods, as shown in figure 3. In China, the Spring Festival periods are usually periods marked by large fluctuations of the interbank offered rate: before the Spring Festival, large sums of cash are withdrawn from commercial banks and this tends to push up the market rate; after the Spring Festival, the cash goes back into the banking system and this tends to push down the market rate. The commercial banks' demand for reserves therefore fluctuates greatly in this period. 


\section{Figure 3. 20-Working-Day Standard Deviation of the Shibor during Spring Festival Periods}

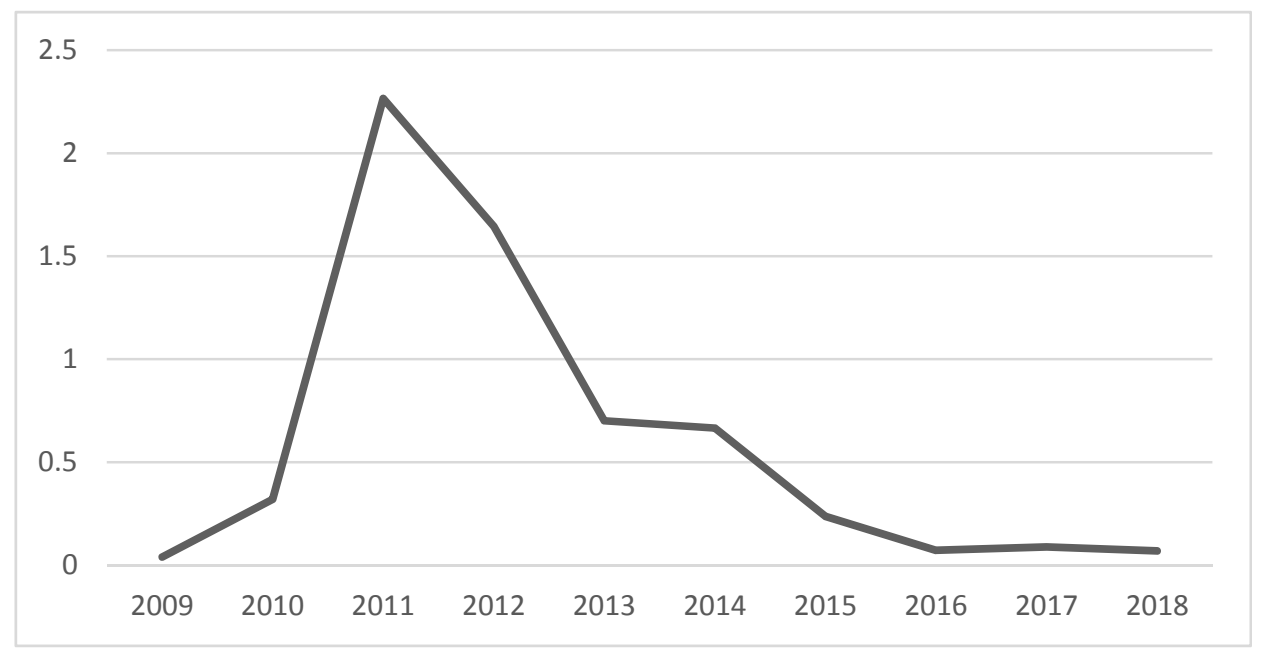

Source: China Foreign Exchange Trade System \& National Interbank Funding Center's website: www.chinamoney.com.cn

However, it doesn't mean that the new monetary policy framework is perfect. Some problems remain to be solved in the new framework.

Firstly, although both the RMB loan interest rate and the RMB deposit interest rate have been deregulated, the PBOC continues announcing their official benchmark rates. How to coordinate the official benchmark rates with the upcoming target rate is a problem. On the one hand, many commercial banks continue using the official benchmark rates as the base to make markup pricing, so these rates now serve as a tool to affect loan interest rate and deposit interest rate. On the other hand, after the deregulation of interest rates, there is a tendency for commercial banks to switch to market rates, like the Shibor, to make their markup pricing, because the market rates better reflect their cost. The target rate in such cases is effective in affecting market interest rates. If both kinds of pricing mechanisms coexist in the market, the effectiveness of the official benchmark rates and that of the upcoming target rate are conflicting. 
Secondly, the change in the required reserves assessment method in 2015 was a double-edged sword for achieving the interest rate target. Since the change, the reserve balance is calculated by the average amount of the reserves during the maintenance period rather than by the amount at the end of each day in the maintenance period. The new assessment method allows financial institutions to not rush into the money market every day to get rid of the excess or accommodate for a shortage of reserves, smoothing the fluctuation of interest rates during the maintenance period. On the other hand, it makes the maintenance period a period to speculate on the future interest rate: "Averaging provisions encourages banks to speculate about daily or even hourly evolutions of the federal funds rate, by modifying their demand for reserves. The markets try to anticipate changes in the target rate, and they try to anticipate the evolution of the federal funds rate around the target rate" (Lavoie 2005). The anticipation may be self-fulfilling (Krieger 2002). The OMOR now has to estimate the speculative demand for reserves. Although the central bank is still able to hit its target rate, the OMOR's difficulty in making the correct estimation is increased.

Finally, how to position the role of the Treasury remains an important problem for China's new monetary policy framework. This problem will be discussed in the next section. 


\section{THE MISSING ROLE OF THE TREASURY IN THE MONETARY POLICY FRAMEWORK}

The role of the Treasury in monetary policy is important because Treasury spending creates money and Treasury taxing destroys it. In a typical modern public finance system, the Treasury holds an account at the central bank and makes payments through it. When the Treasury spends, the central bank decreases the balance on the Treasury's account and increases the balance on a corresponding commercial bank's account. Thus, reserves in the private sector are increased and it pushes the interbank offered rate downward. When the Treasury receives payments from taxes or bonds, the central bank increases the balance on the Treasury's account and decreases the balance on a corresponding commercial bank's account. Thus, reserves in the private sector are decreased, pushing the interbank offered rate upward. Considering the scale of the change in the fiscal balance, in practice a monetary policy framework should take the fiscal effects on reserves into account so that the target rate can be achieved precisely.

In different monetary policy frameworks, the fiscal effects on reserves are dealt with in different ways. In Canada and the United States, the fiscal effects are neutralized by transferring between the Treasury's account at the central bank and its accounts at commercial banks. In Canada, this operation is made by the central bank in the afternoon, "after all settlement transactions with the government are completed," so that "it knows with perfect certainty the amounts that need to be transferred" (Lavoie 2005). In the United States, the Treasury manages its account at the central bank to keep the balance at a certain amount each day. If the Treasury's expenditure is larger than its receipt in one day, the Treasury will transfer reserves from the Treasury Tax and Loan Accounts at commercial banks to its account at the central bank so as to keep the balance constant. Thus, the fiscal effects on reserves are neutralized (Bell 2000). In the monetary policy 
frameworks where the central bank sets the spread of the interest rate corridor to zero, the neutralization is carried out in an automatic way through commercial banks' managing their reserves. For example, if tax payment pushes up the interbank offered rate, the commercial banks will go to the central bank's discount window for reserves and, thus, the fiscal effects will be neutralized. In the monetary policy frameworks where the central bank leaves excessive reserves in the market so as to achieve its target rate at the interest rate paid to excess reserves (Fullwiler 2005), the central bank allows the market to hold excessive reserves so as to neutralize the fiscal effects.

In China's new monetary policy framework, these kinds of coordination mechanisms between the Treasury and the central bank are lacking and the main tool for dealing with the fiscal effects on reserves is its open market operations. To understand the institutional basis of the fiscal effects on reserves in China, the reform of the Treasury account in 2001 is of vital importance, when a Treasury Single Account (TSA) system was established. Before the reform, the Treasury transferred a certain amount of money to different government departments' accounts at commercial banks on a schedule according to the current year's budget. The government departments made payment to the nongovernment sector through their accounts at commercial banks. The old system was decentralized and hard for the Treasury to manage and supervise. After the reform, the TSA system centralized government's receipts and expenditures to the Treasury's account at the PBOC, as shown in figure 4. 
Figure 4. Treasury Single Account System

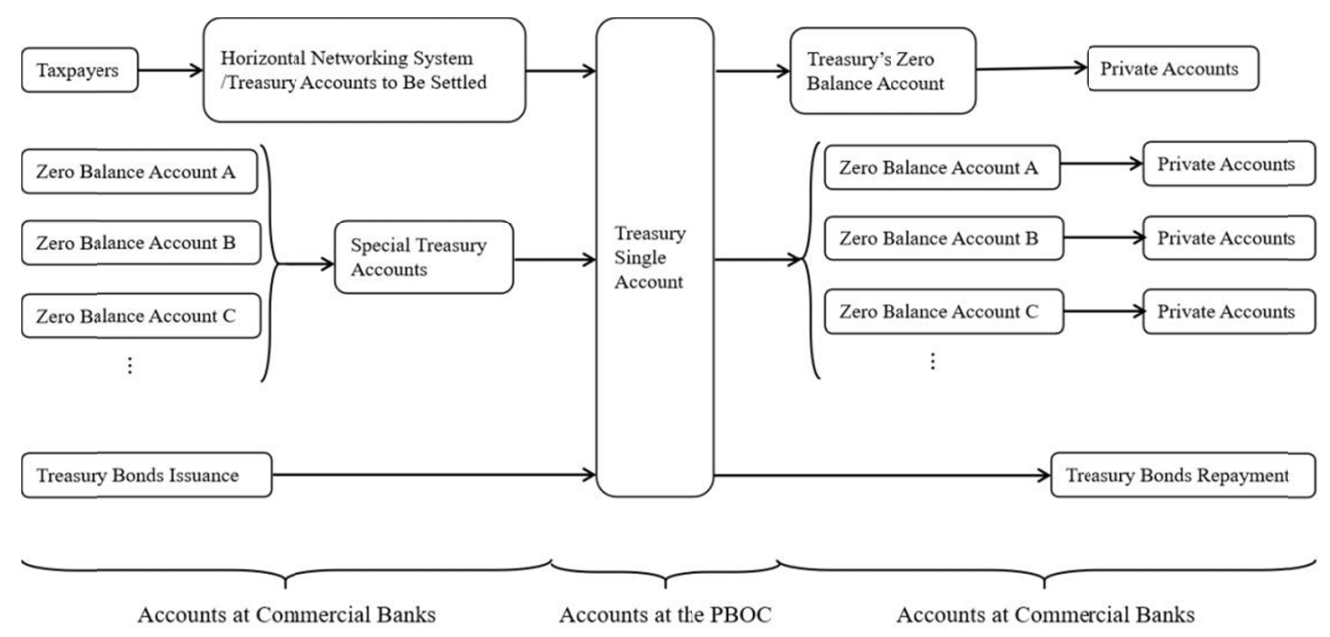

Source: Wei (2013)

The TSA system includes two parts. The first part is the TSA at the PBOC. After the 2001 reform, it included not only the central government's account, but also the accounts of local governments. The second part is the accounts at commercial banks. These include zero balance accounts and special Treasury accounts.

When the government spends, the payments are made through the zero balance accounts at commercial banks. Every governmental department has its own zero balance account and the Treasury's zero balance account is used for certain types of large payments. The balance of these accounts is kept at zero at the end of each day. The payment is made by overdraft and this process is as follows: a government department sends an order to the commercial bank where it holds its zero balance account; the commercial bank credits the zero balance account and debits a corresponding private account; the commercial bank sends a voucher to the central bank; the central bank transfers reserves from the TSA to the commercial bank's account; the commercial bank removes the deficit in the zero balance account and the balance returns to zero. Except for 
some large payments, the reserves are transferred from the TSA to commercial banks' accounts between 15:00 and 16:00 every working day. Its effect on reserves has to wait to be neutralized by the following day's open market operations. As for Treasury bond repayments, they are made directly through the TSA.

When the government receives taxes, the reserves are transferred from commercial banks to the TSA. If the taxpayers make the payment in the Horizontal Networking System — which is a digital tax-payment system - the transfer will be made in real time. If not, the taxes will first be collected in the Treasury accounts to be settled and then the reserves will be transferred to the TSA within one day. As for the nontax revenues in the zero balance accounts, they are first transferred to the special Treasury accounts. After the Treasury checks the related information on the receipts, the reserves are transferred to the TSA. As for Treasury bond issuance, the reserves are transferred directly to the TSA.

In the TSA system, therefore, there is no flexible tool for transferring money between the TSA and the accounts in commercial banks so as to manage the fiscal effects on reserves. In addition to the TSA system, cash management and Treasury bond issuance should also be taken into account. They do not provide flexible tools for managing the fiscal effects on reserves either.

In 2006, a cash management system was established by the Treasury and the PBOC. The major goal, as stated in the Interim Procedures for Central Treasury’s Cash Management, was to minimize the TSA balance and maximize investment returns (Ministry of Finance of the People's Republic of China 2006). There are two kinds of cash management operations at present: fixed-term deposit auction and Treasury bond repurchase. In 2016 and 2017, cash management was all carried out through the fixed-term deposit auction, as shown in table 4 . The 
Treasury's Cash Management Operations Room holds auctions several times a year. It transfers reserves to the commercial banks that win the bid and holds fixed-term deposits in these commercial banks. These operations are infrequent and therefore are not flexible enough for managing the fiscal effects. Besides, it seems that both kinds of cash management operations did not take market conditions into full consideration. Some auctions were held near the end of a month when the government's expenditure reached its peak and injected lots of reserves into the market. The Treasury's first two bond repurchase operations in 2006 and 2008 were not very successful because they were conducted in the periods when the demand for reserves was low.

Table 4. Fixed-Term Deposit Auction of the Central Treasury, 2016-17

\begin{tabular}{|l|l|l|}
\hline Date & $\begin{array}{l}\text { Term } \\
\text { (months) }\end{array}$ & $\begin{array}{l}\text { Amount } \\
\text { (billions } \\
\text { RMB } \\
\text { yuan) }\end{array}$ \\
\hline $2016 / 1 / 19$ & 9 & 80 \\
\hline $2016 / 5 / 27$ & 3 & 40 \\
\hline $2016 / 6 / 16$ & 3 & 80 \\
\hline $2016 / 7 / 21$ & 3 & 50 \\
\hline $2016 / 8 / 23$ & 3 & 50 \\
\hline $2016 / 9 / 14$ & 3 & 60 \\
\hline $2016 / 9 / 20$ & 3 & 60 \\
\hline $2016 / 10 / 24$ & 3 & 80 \\
\hline $2017 / 3 / 16$ & 3 & 60 \\
\hline $2017 / 5 / 19$ & 3 & 80 \\
\hline $2017 / 8 / 18$ & 3 & 80 \\
\hline $2017 / 8 / 24$ & 3 & 80 \\
\hline $2017 / 10 / 16$ & 3 & 80 \\
\hline $2017 / 11 / 17$ & 3 & 120 \\
\hline
\end{tabular}

Source: People's Bank of China's website: www.pbc.gov.cn 
The central government's bonds issuance is also infrequent, as shown in table 5. The infrequence of the issuance makes it hard to make use of Treasury bond issuance to assist the PBOC's operations. Besides, the above is also true for the local governments' cash management and bond issuance, which are more irregular and have a larger scale than the central government's. 
Table 5. Central Government's Bonds Issuance, 2016-17

\begin{tabular}{|c|c|c|c|c|c|}
\hline Bonds Issuance Period & $\begin{array}{c}\text { Term } \\
\text { (years) }\end{array}$ & \begin{tabular}{|l} 
Amount \\
(billions \\
RMB yuan)
\end{tabular} & Bonds Issuance Period & $\begin{array}{c}\text { Term } \\
\text { (years) }\end{array}$ & $\begin{array}{l}\text { Amount } \\
\text { (billions } \\
\text { RMB yuan) }\end{array}$ \\
\hline $2016 / 03 / 10-2016 / 03 / 19$ & 3 & 14.983 & 2017/03/10-2017/03/19 & 3 & 14.87 \\
\hline $2016 / 03 / 10-2016 / 03 / 19$ & 5 & 14.981 & 2017/03/10-2017/03/19 & 5 & 14.889 \\
\hline $2016 / 04 / 10-2016 / 04 / 19$ & 3 & 20 & 2017/04/10-2017/04/19 & 3 & 21.613 \\
\hline 2016/04/10-2016/04/19 & 5 & 20 & 2017/04/10-2017/04/19 & 5 & 23 \\
\hline $2016 / 05 / 10-2016 / 05 / 19$ & 3 & 14.925 & 2017/05/10-2017/05/19 & 3 & 15.951 \\
\hline $2016 / 05 / 10-2016 / 05 / 19$ & 5 & 14.954 & $2017 / 05 / 10-2017 / 05 / 19$ & 5 & 17.214 \\
\hline $2016 / 06 / 10-2016 / 06 / 19$ & 3 & 20 & $2017 / 06 / 10-2017 / 06 / 19$ & 3 & 13.606 \\
\hline 2016/06/10-2016/06/19 & 5 & 20 & 2017/06/10-2017/06/19 & 5 & 22.06 \\
\hline 2016/07/10-2016/07/19 & 3 & 19.189 & 2017/07/10-2017/07/19 & 3 & 15.239 \\
\hline 2016/07/10-2016/07/19 & 5 & 20 & 2017/07/10-2017/07/19 & 5 & 18.842 \\
\hline 2016/08/10-2016/08/19 & 3 & 20 & 2017/08/10-2017/08/19 & 3 & 18.32 \\
\hline 2016/08/10-2016/08/19 & 5 & 20 & 2017/08/10-2017/08/19 & 5 & 22.964 \\
\hline 2016/09/10-2016/09/19 & 3 & 14.661 & 2017/09/10-2017/09/19 & 3 & 16.612 \\
\hline 2016/09/10-2016/09/19 & 5 & 14.711 & 2017/09/10-2017/09/19 & 5 & 15.981 \\
\hline 2016/10/10-2016/10/19 & 3 & 20 & 2017/10/10-2017/10/19 & 3 & 16.196 \\
\hline $2016 / 10 / 10-2016 / 10 / 19$ & 5 & 20 & 2017/10/10-2017/10/19 & 5 & 22.689 \\
\hline $2016 / 11 / 10-2016 / 11 / 19$ & 3 & 14.914 & 2017/11/10-2017/11/19 & 3 & 16.243 \\
\hline $2016 / 11 / 10-2016 / 11 / 19$ & 5 & 14.945 & 2017/11/10-2017/11/19 & 5 & 15.239 \\
\hline
\end{tabular}

Source: People's Bank of China's website: www.pbc.gov.cn 
In China's monetary policy framework, the burden of managing the effects therefore falls on the shoulders of the OMOR. Under the "peak shaving and valley filling" principle, if the fiscal effects on reserves are not offset by other factors, the OMOR would inject reserves during the tax payment period or when Treasury bonds are issued, and absorb reserves when the government spends.

However, it is not an easy task for the OMOR to fully neutralize the fiscal effects on reserves for the following reasons. Firstly, the uncertainty of the government's expenditures and receipts increases the PBOC's difficulty in achieving the target rate. Because the government's expenditures and receipts rely on economic conditions to some degree and economic conditions are full of uncertainty, it is a matter of skill and luck for the OMOR to make correct estimations about the effects of fiscal activities.

Secondly, the periodic variation of the balance in the TSA is very large. It is not only because the scale of the expenditures and receipts is very large, but also because the periodic variation of the expenditures and that of receipts do not coincide with each other. On the one hand, the tax payment deadline is, for the most part, in the middle of a month or in the middle of the first month of a season. Thus, tax payments usually reach their peak in the middle of a month and in the first month of a season. On the other hand, expenditures reach their peak at the end of a month, because many types of payments have to be made before each government department prepares its financial statement at the end of the month. Besides, because the budget of a department relies on last year's balance (the Treasury usually increases the budget when it is not enough to cover a department's expenditure), it gives the government departments an incentive to spend more at the end of a year. This is one of the reasons why expenditures reach their peak at the end of a year. As shown in figure 6, in months with large fiscal expenditures or receipts, 
the balance change might be two to five times the total excess reserves in the financial system.

\section{Figure 5. Monthly Change in the TSA}

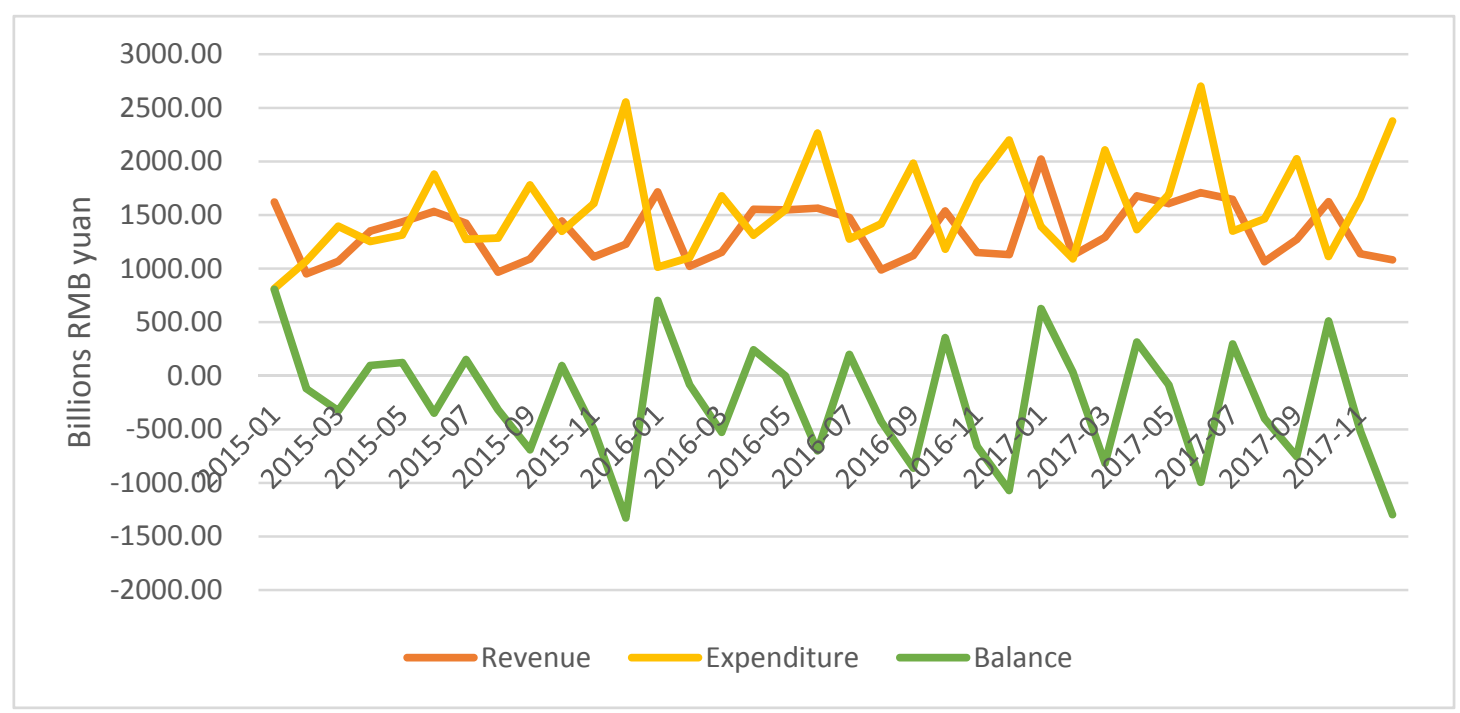

Source: CEInet Industry Database

Thirdly, the local governments' expenditures and receipts have the same effect on reserves as the central government's because the TSA includes the local governments' accounts. It makes the fiscal effects on reserves bigger than the case where local governments do not hold accounts at the central bank. Generally, the periodic variation in the local governments' receipts and expenditures is similar to that of the central government's. This similarity was reinforced by the merger between the National Taxation Bureau and the Local Taxation Bureau in 2018. Before the merger, in some cases the Local Taxation Bureau set the payment periods for local taxes to be different from the payment periods for national taxes. The end of the payment period for some kinds of local taxes was set at the 10 th or 20 th of a month. To some extent, this smoothed the effect of tax payments on reserves. After the merger, however, the difference in the payment periods was eliminated. 
In short, there is no specialized tool for managing the fiscal effects on reserves in China's monetary policy framework. At present, the main tool to offset it is open market operations and this requires the OMOR to have great skill and luck in precisely estimating the fiscal effects on reserves. Considering the scale and uncertainty of the fiscal activities, further reform is needed to provide a coordination mechanism between the Treasury and the PBOC.

\section{CONCLUSION}

The institutional evolution of China's monetary policy framework is closely related to China's marketization process. The rapid growth of the market economy after 1978 pushed the government to abandon its direct control on finance and to build up a financial market. In the transitional stage, when the financial market was not mature and the direct control on finance was not abandoned entirely, the old monetary policy framework was built to affect financial activity. However, due to the rapid development of the financial markets, the old framework became more and more problematic and it forced the PBOC to make an institutional transformation to a new framework in the new century.

The reform of the monetary policy framework has been successful and two important changes provide the institutional basis for the success of the reform: establishing an interest rate corridor and decreasing the OMOR's difficulty in estimating the market demand for reserves. These changes make it easier for the PBOC to stabilize the interbank offered rate. Following the reform, the interest rate maintenance mode in the new framework is clear: the interbank offered rate is kept within the interest rate corridor and how precisely the target rate can be achieved depends on how precisely the OMOR can estimate and meet the market demand for reserves. 
For future reforms, cooperation between the central government and the PBOC is necessary. The powers of different government departments may need to be reallocated in the new monetary policy framework. Firstly, cooperation is needed to replace the old intermediate target with a new one. At present, the money quantity target and official benchmark rates are controlled by the central government and the monetary policy tools and their interest rates are controlled by the PBOC. While it is obvious that a new target rate is needed to replace the old target in the future, the question of who should control the new target is a political problem. Secondly, cooperation between the Treasury and the PBOC is needed so as to manage the fiscal effects on reserves. One possible solution to the problem of how to manage the fiscal effects is the opening of special accounts at commercial banks so as to control the balance of the TSA by transferring between the TSA and the special accounts. However, it would not be an easy task to reform the TSA system. It has long been a controversial question in China whether the central bank should be a manager or an agency of the TSA. The reform can be carried out only when both sides are satisfied with the new system. Therefore, it is to some degree a political problem how the reform of China's monetary policy framework will be carried out in the future. Like the old Chinese saying, “行百里者半九十” (Ninety miles is only half of a hundred miles journey), the remaining part of a reform is usually the hardest part. So is the reform of China's monetary policy framework. 


\section{REFERENCES}

Bell, S. 2000. "Do Taxes and Bonds Finance Government Spending?" Journal of Economic Issues 34(3): 603-20.

Bell, S., and L. R. Wray. 2002. "Fiscal Effects on Reserves and the Independence of the Fed." Journal of Post Keynesian Economics 25(2): 263-71.

Central People's Government of the People's Republic of China. 2018. "Report on the Work of the Government." Report Delivered at the First Session of the 13th National People's Congress of the People's Republic of China on March 5 (In Chinese). Accessed on February 6, 2019. Available at:

http://www.pbc.gov.cn/zhengcehuobisi/125207/125227/125957/126003/2843719/index. html.

Fullwiler, S. T. 2005. "Paying Interest on Reserve Balances: It's More Significant than You Think." Journal of Economic Issues 39(2): 543-50.

— 2013. "Modern Central Bank Operations: The General Principles." In Basil Moore and Louis-Philippe Rochon (eds.), Post-Keynesian Monetary Theory and Policy: Horizontalism and Structuralism Revisited. Cheltenham, UK: Edward Elgar.

Gang, Yi. 2018. "Retrospect and Prospect of Monetary Policy." (In Chinese) Chinese Finance (3): 9-14.

Krieger, S. C. 2002. "Recent Trends in Monetary Policy Implementation: A View from the Desk." Federal Reserve Bank of New York Economic Policy Review 8(1): 73-76.

Lavoie, M. 2005. "Monetary Base Endogeneity and the New Procedures of the Asset-based Canadian and American Monetary Systems." Journal of Post Keynesian Economics 27(4): 689-709.

Leung, M. K., and Q. Lu. 2011. "Changing Money Market and Monetary Policy Operations in China: an Institutional Perspective.” Journal of Contemporary China 20(69): 287-305. 
Ministry of Finance of the People's Republic of China. 2006. "Interim Procedures for Central Treasury’s Cash Management.” (In Chinese) Accessed on March 24, 2019. Available at: http://gks.mof.gov.cn/guokuxianjinguanli/200807/t20080725_58828.html.

People's Bank of China (PBOC). 2009. “China Monetary Policy Report Quarter One, 2009.” (In Chinese) Accessed on December 7, 2018. Available at: http://www.pbc.gov.cn/zhengcehuobisi/125207/125227/125957/126003/2843719/index. html.

_. 2013a. "China Monetary Policy Report Quarter One, 2013.” (In Chinese) Accessed on December 7, 2018. Available at:

http://www.pbc.gov.cn/zhengcehuobisi/125207/125227/125957/125991/2907288/index. html.

_. 2013b. "China Monetary Policy Report Quarter Three, 2013.” (In Chinese) Accessed on December 7, 2018. Available at: http://www.pbc.gov.cn/zhengcehuobisi/125207/125227/125957/125991/2907288/index. html.

—. 2017a. "China Monetary Policy Report Quarter One, 2017.” (In Chinese) Accessed on December 7, 2018. Available at:

http://www.pbc.gov.cn/zhengcehuobisi/125207/125227/125957/3307990/3307409/index .html.

—. 2017b. "China Monetary Policy Report Quarter Four, 2017.” (In Chinese) Accessed on December 7, 2018. Available at:

http://www.pbc.gov.cn/zhengcehuobisi/125207/125227/125957/3307990/3484662/index .html.

—. 2018. "China Monetary Policy Report Quarter One, 2018.” (In Chinese) Accessed on December 7, 2018. Available at:

http://www.pbc.gov.cn/zhengcehuobisi/125207/125227/125957/3537682/3537621/index .html.

Tymoigne, E. 2014. "Modern Money Theory, and Interrelations between the Treasury and Central Bank: The Case of the United States." Journal of Economic Issues 48(3): 64162. 
Wei, Zhong. 2013. "Special Report on Treasury Part One: Improving Treasury Cash Management and Activating Treasury Fund." (In Chinese) Research Report. Ping An Securities. August.

Wray, L. R. 2015. Modern Money Theory: A Primer on Macroeconomics for Sovereign Monetary Systems. Basingstoke, UK: Palgrave.

Xiaochuan, Zhou. 2004. "Some Considerations in the Study of Monetary Policy Transmission." (In Chinese) December 7, 2018. Available at: http://www.pbc.gov.cn/hanglingdao/128697/128719/128766/2835231/index.html.

Zhong, Xu. 2018 "Transformation of Monetary Policy in the High-Quality Development Stage." (In Chinese) PBOC Working Paper 2018/3. Beijing: People's Bank of China. Available at: http://www.pbc.gov.cn/yanjiuju/124427/133100/3487653/3559889/index.html. 


\section{APPENDIX: MODERN MONEY THEORY AND CHINA'S PRACTICE}

This paper provides some institutional details for analyzing China's financial system using a Modern Money Theory (MMT) framework. According to MMT, a government with currency sovereignty is always spending by creating money and there is no internal financial constraint for the government to do so. Every government does face constraints because of the budget set by their congress, but they do not face a constraint because the Treasury does not have enough money.

Traditional opinions hold that there are internal constraints for the government's ability to spend by creating money. These constraints include that the Treasury can spend only when its balance at the central bank is positive and that the central bank is banned from buying Treasury bonds in the primary market. Adherents of MMT state that these internal constraints can be bypassed easily. Considering the fiscal effects on reserves, it is necessary for the central bank to cooperate with the Treasury to bypass the self-imposed constraints, because the central bank's responsibility is to protect the stability of the domestic payment system and keep it from a liquidity crisis. It is a common practice for a central bank to buy Treasury bonds in the secondary market so as to inject reserves into the market before a Treasury bonds issuance. By keeping the financial market stable and supplied with enough reserves, the central bank creates a financial situation in which the Treasury bond auction is easily successful. If the central bank refuses to do so, the shortage of reserves caused by the Treasury bond issuance may destabilize the payment system and this would violate the central bank's responsibility. With a well-designed Treasury bond auction system — or other financial instruments (such as tax-anticipation bills) - the self-imposed constraints can therefore be bypassed easily and the 
result is exactly the same as when the Treasury sells bonds directly to the central bank. ${ }^{3}$

This is also true for China. In China, how the Chinese government's fiscal activities affect reserves can be observed in the Treasury Single Account (TSA) system. It is clear that fiscal activities have a direct impact on money and how to manage the impact is now an important problem in China's new monetary framework. One interesting fact in China is that both the central government's and the local governments' spending create money (as we explain in the third section of the paper), but only the central government is able to bypass the internal financial constraints. The constraints here mean that China's government can spend only when the balance in the TSA is positive; the PBOC cannot provide overdraft facilities for the TSA and cannot buy Treasury bonds in the primary market.

For China's central government, there are no internal financial constraints for its spending by creating money. The self-imposed constraints can be bypassed easily with the cooperation of the PBOC. Under the "peak shaving and valley filling" principle, the OMOR injects reserves into the market in the periods when a large sum of reserves is transferred to the TSA due to the Treasury bonds issuance. The reason for the PBOC to do so is not that it does not have enough independence. Rather, its responsibility as a central bank to protect the stability of the domestic payment system requires it to do so. Because the PBOC creates a financial situation in which the Treasury bond auction is easily successful by keeping the financial market stable and supplied with enough reserves, it is hard for commercial banks to refuse the Treasury bonds-which are not only profitable but also highly liquid. With a stable financial market and a well-functioning Treasury bond auction system, the central government can surpass constraints without much difficulty.

\footnotetext{
${ }^{3}$ For more details about this process, please refer to Wray (2015).
} 
For China's local governments, however, the constraints on them are imposed by the central government and the PBOC rather than by themselves. The total number of local government bonds is limited by the central government. Even if the local governments issue debts through financial innovation so as to bypass the limits, these debts would not be acceptable for getting liquidity from the central bank. Without the support of the central government and the central bank, whether these debts can be issued successfully relies on the market's assessment on the local governments' financial situation. If a local government falls into a Ponzi finance situation, in which its income flow cannot cover the principal and interest of its debts, it may fail to roll over its debts and go bankrupt. 